\title{
“KNOWLEDGE MANAGEMENT” PADA KELOMPOK TANI KARYA BERSAMA, DI DESA TOMBASIAN ATAS KECAMATAN KAWANGKOAN BARAT, KABUPATEN MINAHASA
}

\author{
Raldy H. Assa \\ Leonardus Ricky Rengkung \\ Caroline B. D. Pakasi
}

\begin{abstract}
ABSRACT
The purpose of this paper is to know the Knowledge Management of "Karya Bersama" farmers group at Tombasian Atas Village, Kawangkoan West, Minahasa District. This research was conducted from April to July 2016. The data used in this research are primary and secondary data. The variables measured were knowledge identification, knowledge creation, knowledge presentation and knowledge distribution. The analysis used is descriptive qualitative analysis by using content analysis. The results showed that the identification of group knowledge through cultivation, mass media, experience, TV media, newspapers and books, the presence of extension workers and among group members. Knowledge creation occurs through regular meetings among farmer groups. Knowledge presentation is carried out by exploiting technology utilization, demonstrating farming tools and distributing the knowledge gained. *lrr*
\end{abstract}

Keywords: knowledge management, identification, creation, presentation, distribution, farmer group, Upper Tombasian Village, Minahasa Regency

\begin{abstract}
ABSTRAK
Tujuan penulisan ini adalah untuk mengetahui Knowledge Management kelompok tani "Karya bersama" Desa Tombasian Atas, Kecamatan Kawangkoan Barat, Kabupaten Minahasa. Penelitian ini dilaksanakan dari bulan April sampai Juli 2016. Data yang digunakan dalam penelitian ini adalah data primer dan sekunder. Variabel yang diukur adalah identifikasi pengetahuan, penciptaan pengetahuan, presentasi pengetahuan dan distribusi pengetahuan. Analisis yang digunakan adalah analisis deskriptif kualitatif dengan menggunakan content analysis. Hasil menunjukkan bahwa identifikasi pengetahuan kelompok melalui bercocok tanam, media masa, pengalaman, media TV, membaca koran dan buku, kehadiran penyuluh dan antar anggota kelompok. Penciptaan pengetahuan terjadi melalui pertemuan rutin antar kelompok tani. Persentase pengetahuan dilakukan dengan cara pemanfaatan teknologi, demonstrasi alat-alat pertanian mendistribusikan pengetahuan yang didapat.
\end{abstract}

Kata kunci : Knowledge Management, identifikasi, penciptaan, presentasi, distribusi, kelompok tani, Desa Tombasian Atas, Kabupaten Minahasa 


\section{PENDAHULUAN}

\section{Latar Belakang}

Pemerintah suatu negara memperhatikan permasalahan yang dihadapi oleh petani antara lain pemberian modal usaha berupa mesin traktor, benih, pupuk, dan pestisida. Pemberian bantuan ini harus melalui organisasi kelompok tani. Desa Tombasian Atas sampai saat ini sudah terbentuk beberapa kelompok tani, diantaranya kelompok tani "Karya Bersama". Kelompok tani karya bersama dalam melaksanakan kegiatan didahului dengan penyusunan rencana (planning) dan dalam memantapkan program diadakan pertemuan secara rutin antara pimpinan kelompok dan anggota kelompok (menggorganisir) selanjutnya melaksanakan kegiatan sesuai sesuai dengan perencanaan (actuating). Ketika kegiatan ini sedang berjalan pimpinan selalu mengontrol anggota yang melakukan kegiatan (controlling) sehingga ketika kegiatan berakhir maka diadakan evaluasi tentang hambatanhambatan/permasalahan atau keunggulan/ keuntungan dari hasil kegiatan tersebut (evaluating). Kelompok tani karya bersama dibentuk berawal dari kegiatan rukun keluarga yang kemudian membentuk kelompok tani, kegiatanya menanam jagung dan kacang tanah. Ketika kurang lebih satu tahun kegiatan berlangsung kelompok mendapat bantuan benih jagung, kacang dan pupuk. Pada saat panen pertama berhasil sehingga dapat memperluas usaha yakni pengelolahan kacang tanah untuk disangrai kemudian dipasarkan. Dari hasil evaluasi dan monitoring dari dinas terkait maka kelompok tani mendapat peringkat terbaik di tingkat Propinsi sehingga mendapat tropi dari gubernur disertai dengan bantuan yang mendukungusaha kelompok tani. Selain penghargaan kelompok tani juga dinaikan kelasnya dari kelas pemula ke kelas lanjutan dan setahun kemudian dinaikan lagi dari kelas lanjutan kekelas madya. Kelompok tani didefinisikan sebagai kumpulan orang-orang tani atau petani, yang terdiri atas petani dewasa, petani wanita, tua dan muda, yang terikat secara informal dalam suatu wilayah kelompok atas dasar keserasian dan kebutuhan bersama serta berada dilingkungan pengaruh dan pimpinan seorang kontak tani. Kelompok tani merupakan kelembagaan tani yang langsung mengorganisir para petani dalam menggembangkan usahanya.Kelompok tani merupakan organisasi yang dapat dikatakan berfungsi dan ada secara nyata, disamping berfungsi sebagai wahana penyuluhan dan pengerak kegiatan anggotanya. Tujuan Kelompok Tani adalah untuk mensejahterakan anggota, mendapatkan pengetahuan tentang cara menanam jagung, kacang tanah, padi dan tanaman lainnya, serta cara penanggulangan hama penyakit yang sesuai dengan hasil penelitian para ahli. Kegiatan yang dilakukan oleh kelompok tani "Karya Bersama" berupa penanaman jagung, kacang tanah, dan padi serta pertemuan anggota secara rutin dua minggu sekali digilir pada setiap anggota. Kelompok tani ini juga sempat mengolah kacang tanah hasil panen kelompok tani kemudian disangrai menjadi kacang tore lalu dipasarkan.

Dalam proses/kegiatan yang dilakukan oleh kelompok tani ini sebagai suatu organisasi terdapat dalam beberapa hal, antara lain Knowledge Manajemen. Pengetahuan yang dimiliki oleh organisasi harus mampu memberikan kemajuan bagi organisasi itu sendiri supaya bertahan hidup, maka diwajibkan setiap orang yang ada didalam organisasi sharing pengetahuan. Untuk itu dibutuhkan manajemen yang kuat agar pengetahuan tersebut mengakar di setiap individu dalam organisasi dan tidak hilang begitu saja dengan dukungan infrastruktur untuk penyebaran informasi di lingkungan organisasi. Perkembangan dewasa ini dengan semakin cepatnya perubahan organisasi akibat dari efek globalisasi serta pengembangan teknologi informasi yang sangat akseleratif, maka membutuhkan cara - cara baru dalam menyikapi semua yang terjadi agar organisasi dapat bertahan. Penekanan akan pentingnya kualitas sumber daya manusia (SDM) merupakan salah satu respons dalam menyikapi perubahan tersebut. Dan ini tentu saja memerlukan upayaupaya untuk meningkatkan dan mengembangkan sumber daya manusia (SDM). Sehubungan dengan itu peranan ilmu pengetahuan makin menonjol, karena hanya dengan pengetahuanlah semua perubahan yang terjadi dapat disikapi dengan tepat. Ini berarti pendidikan semakin penting dalam mempersiapkan SDM yang berkualitas dan kompetitif. Pengetahuan telah menjadi 
sesuatu yang sangat menentukan. Oleh karena itu, perolehan dan pemanfaatannya perlu dikelolah dengan baik dalam konteks peningkatan kinerja organisasi. Langkah ini dipandang sebagai sesuatu yang sangat strategis dalam menghadapi persaingan yang mengelobal, sehingga pencapaiannya akan merupakan suatu bencana bagi dunia bisnis. Oleh karena itu, diperlukan cara yang dapat mengintegrasikan pengetahuan itu dalam kerangka pengembangan sumber daya manusia dalam organisasi. Dari inilah istilah manajemen pengetahuan berkembang sebagai suatu bagian penting dan strategis dalam pengelolaan sumber daya manusia pada perusahaan/organisasi. Pengetahuan diperlukan sebagai bagian dari upaya meningkatkan kinerja organisasi melalui pengintegrasiannya dengan proses organisasi. Untuk itu organisasi perlu melakukan pengembangan dirinya menjadi organisasi pembelajar melalui mengelolah pengetahuan. Hal yang esensial dalam Knowledge Management adalah terbentuknya lingkungan belajar yang kondusif sehingga para pekerja termotivasi untuk terus belajar memanfaatkan informasi atau pengetahuan yang disediakan perusahaan dan menumbuhkembangkan pengetahuan individualnya serta pada akhirnya mau berbagi pengetahuan baru yang didapatkan untuk menjadi pengetahuan organisasi, atau dengan kata lain Knowledge Management fokus agar manusia didalamnya produktif untuk menumbuhkembangkan pengetahuan dan mau berbagi pengetahuan yang dimilikinya.

Kelompok tani merupakan kelembagaan tani yang langsung mengorganisir para petani dalam menggembangkan usahanya. Kelompok tani merupakan organisasi yang dapat dikatakan berfungsi dan ada secara nyata, disamping berfungsi sebagai wahana penyuluhan dan penggerak kegiatan anggotanya. Dengan demikian, maka kelompok tani yang merupakan suatu organisasi harus memiliki pengetahuan manajemen dalam rangka peningkatan produktifitas untuk kesejahteraan semua anggota. Jadi mulai dari merencanakan kegiatan, mengorganisir anggota kelompok sampai pada mengontrol kegiatan terlihat lemah apalagi dalam proses pembelajaran dan saling membelajarkan satu sama lain sesuai dengan pengetahuan atau pengalaman yang dimiliki baik pimpinan maupun anggota kelompok.

\section{Rumusan Masalah}

Bagaimana Knowledge Management pada kelompok tani "Karya Bersama" Desa Tombasian Atas Kecamatan Kawangkoan Barat Kabupaten Minahasa.

\section{Tujuan}

Tujuan penulisan ini adalah untuk mengetahui kemampuan Knowledge Management kelompok tani "Karya bersama" Desa Tombasian Atas, Kecamatan Kawangkoan Barat, Kabupaten Minahasa dalam aspek identifikasi pengetahuan, penciptaan pengetahuan, pengolahan pengetahuan dan distribusi pengetahuan.

\section{Manfaat Penelitian}

Hasil penelitian ini diharapkan dapat bermanfaat dan menjadi sumbangan ilmu pengetahuan serta informasi tentang Knowledge Management pada Kelompok Tani "Karya Bersama" Desa Tombasian Atas, Kecamatan Kawangkoan Barat, Kabupaten Minahasa.

\section{METODOLOGI PENELITIAN}

\section{Waktu Dan Tempat Penelitian}

Penelitian ini dilakukan pada bulan April sampai bulan Juli 2016, dari persiapan, pengambilan data, tabulasi, dan analisis data hingga penyusunan laporan hasil penelitian. Kegiatan ini dilakukan di Desa Tombasian Atas, Kecamatan Kawangkoan Barat, Kabupaten Minahasa, Provinsi Sulawesi Utara.

\section{Metode Pengumpulan Data}

Data yang digunakan dalam penelitian ini adalah data primer dengan pengambilan data mengunakan metode interview terhadap anggota maupun pengurus kelompok tani dengan tujuan untuk mengetahui sumber Knowledge Management dalam kelompok tani. 


\section{Konsep Pengukuran Variabel}

Variabel yang menjadi kajian dalam penelitian ini berkaitan dengan Knowledge Management adalah:

a. Mengidentifikasi pengetahuan: membaca buku, menonton TV, mendengarkan radio, membaca koran, penyuluhan pertanian, mengikuti seminar, mengikuti pelatihan pelatihan.

b. Menciptakan pengetahuan berdasarkan pengalaman yang mereka temukan dengan cara: diskusi sesama anggota kelompok tani, diskusi antar kelompok tani, berupaya mencari informasi yang baru dan inovasi.

c. Mempresentasikan pengetahuan kepada anggota kelompok tani dengan cara: mengumpulkan semua anggota untuk menyaksikan presentasi tentang pemanfaatan teknologi pertanian, mendemonstrasikan pemanfaatan peralatan pertanian yang terkait dengan usaha yang dikerjakan, mempresentasikan semua keberhasilan usaha pertanian.

d. Mendistribusikan pengetahuan kepada anggota kelompok tani untuk dipergunakan kembali dengan cara mendiskusikan pengetahuan yang diterima.

\section{Analisis Data}

Analisis data yang digunakan merupakan analisis deskriptif kualitatif dengan menggunakan content analysis. Metode analisis isi pada dasarnya merupakan suatu teknik sistemik untuk menganalisis isi pesan dan mengolah pesan, atau suatu alat untuk mengobservasi dan menganalisis isi perilaku komunikasi yang terbuka dari komunikator yang dipilih dalam analisis ini akan diketahui kemampuan Knowledge Management pada kelompok tani "Karya Bersama" Desa Tombasian Atas.

\section{HASIL PENELITIAN}

\section{Deskripsi Wilayah Penelitian}

\section{Sejarah Desa}

Desa Tombasian Atas atau "Tou in Wasian" yang merupakan legenda Minahasa, kononnya tempat tersebut tumbuh pohon yang sangat besar yang bernama Wasian, pohon wasian ini sebesar lapangan sepak bola. Tombasian Atas adalah Desa di Kecamatan Kawangkoan Barat, Kabupaten Minahasa. Sebagian besar penduduk Desa Tombasian Atas memiliki keahlian dalam pengolahan nira aren menjadi alkohol berkualitas tinggi (cap tikus) yang mempunyai kadar alkohol hingga $80 \%$. Selain itu, masyarakat Desa Tombasian Atas mengembangkan ketrampilan mereka dalam bidang konstruksi bangunan rumah kayu (rumah panggung) yang saat ini pemasaran atau penjualannya telah sampai keluar daerah. Desa Tombasian Atas memanfaatkan air tanah dari pegunungan Rindengan yang murni sebagai kebutuhan sehari-hari bahkan saat ini telah ada anggota masyarakat yang telah memanfaatkannya sebagai sumber penghasilan di bidang pengisian ulang air minum.

\section{Demografi Wilayah}

Letak wilayah Desa Tombasian Atas adalah sebuah desa yang terletak di wilayah Kecamatan Kawangkoan Barat, Kabupaten Minahasa, Propinsi Sulawesi Utara. Terdiri dari 5 jaga/dusun yaitu Jaga I, Jaga II, Jaga III, Jaga IV, dan Jaga V dengan batas wilayah yaitu :

Sebelah utara : Desa Tombasian Atas Satu

Sebelah timur : Desa Kanonang Satu

Sebelah selatan: Pegunungan Rindengan

Sebelah barat : DesaTombasianBawah

Luas wilayah Desa Tombasian Atas memanjang dari Utara ke Selatan dengan luas $117 \mathrm{Ha}$, beriklim tropis dan berada pada ketinggian 700 meter di atas permukaan laut sehingga Desa Tombasian Atas termasuk daerah dataran tinggi di Minahasa.

\section{Visi dan Misi Desa Tombasian Atas, Kecamatan Kawangkoan Barat}

a. Visi

Menjadikan masyarakat yang mandiri sehat jasmani, rohani, sosial budaya, menuju masyarakat adil dan sejahtera.

b. Misi
1) Meningkatkan sarana dan prasarana pertanian.
2) Pengembangan agri bisnis berbasis kelompok.
3) Meningkatkan kualitas sumber daya manusia.


4) Meningkatkan sarana dan fasilitas pelayanan kesehatan masyarakat.

5) Pengembangan ekonomi masyarakat.

6) Memelihara, melestarikan budaya gotong royong.

7) Meningkatkan sarana dan prasarana tempat ibadah.

\section{Data geografis}

Keadaan perekonomian yang ada di desa Tombasian Atas sebagian besar masyarakat bermata pencaharian sebagai petani, pedagang dan guru. Jumlah penduduk 1056 jiwa, laki-laki 535 jiwa, perempuan 521 jiwa.

\section{Karakteristik Responden}

\section{Umur Responden}

Tingkat umur mempengaruhi kemampuan seseorang dalam melakukan aktivitas maupun konsep berpikir.Pada umumnya, responden yang berumur muda memiliki kondisi fisik lebih kuat dibandingkan dengan responden yang berumur tua. Komposisi umur responden dalam penelitian ini disajiakan pada Tabel 1.

Tabel 1. Jumlah Responden Menurut Tingkat

\begin{tabular}{lccc} 
No & $\begin{array}{c}\text { Umur } \\
\text { (Tahun) }\end{array}$ & $\begin{array}{c}\text { Responden } \\
\text { (Orang) }\end{array}$ & $\begin{array}{c}\text { Persentase } \\
(\%)\end{array}$ \\
\hline 1. & $21-40$ & 5 & 25 \\
2. & $41-60$ & 9 & 45 \\
3. & $61-80$ & 6 & 30 \\
\hline \multicolumn{4}{l}{ Sumber $:$ Diolah data Primer, 2016} \\
\hline
\end{tabular}

Sumber : Diolah data Primer, 2016

Tabel 1 menunjukkan bahwa jumlah responden terbanyak berada pada interval umur 41-60 tahun (45\%) dan selanjutnya pada interval umur 61-80 tahun (30\%), dan yang paling sedikit responden yang berada pada interval umur 21-40 tahun (25\%).

\section{Tingkat Pendidikan Responden}

Tingkah laku individu atau seseorang sangat di pengaruhi oleh pendidikan yang telah dicapai, begitu juga pada anggota kelompok tani pendidikan akan mempengaruhi pengetahuan memanajemen suatu usaha tani.

\begin{tabular}{|c|c|c|c|}
\hline Tabel & $\begin{array}{l}\text { 2. Jumla } \\
\text { Pend }\end{array}$ & $\begin{array}{l}\text { Responden } \\
\text { kan }\end{array}$ & Tingkat \\
\hline No & $\begin{array}{c}\text { Tingkat } \\
\text { Pendidikan }\end{array}$ & $\begin{array}{c}\text { Jumlah Responden } \\
\text { (orang) }\end{array}$ & $\begin{array}{c}\text { Persentase } \\
(\%)\end{array}$ \\
\hline 1. & SD & 6 & 30 \\
\hline 2. & SMP & 4 & 20 \\
\hline 3. & SMA & 7 & 35 \\
\hline 4. & S1 & 3 & 15 \\
\hline & Jumlah & 20 & 100 \\
\hline
\end{tabular}

Sumber : Diolah data Primer, 2016

Tabel 2 menunjukkan tingkat pendidikan yang dimiliki responden. Dan tingkat pendidikan responden yang paling banyak yaitu SMA sebanyak 7 responden (35\%), selanjutnya tingkat SD sebanyak 6 responden (30\%), selanjutnya tingkat pendidikan SMP sebanyak 4 responden (20\%), dan tingkat pendidikan responden paling sedikit S1 sebanyak 3 responden (15\%).

\section{Knowledge Management Kelompok Tani "Karya Bersama"}

Knowledge Management adalah praktek-praktek atau disiplin yang pilarnya adalah manusia, sistem, dan teknologi yang dianggap sebagai suatu rangkaian kegiatan yang digunakan oleh organisasi atau perusahaan untuk mengidentifikasi, menciptakan, menjelaskan dan mendistribusikan pengetahuan untuk digunakan kembali, diketahui dan dipelajari di dalam organisasi. Deveau (2000) mengemukakan bahwa Knowledge Management adalah pengaplikasian secara efektif suatu teknologi pada pikiran atau otak karyawan. Penelitian ini menjelaskan tentang Knowledge Management pada Kelompok Tani Karya Bersama berdasarkan pada aspek-aspek mengidentifikasi pengetahuan, menciptakan pengetahuan, mengelola pengetahuan dan mendistribusikan pengetahuan.

\section{Identifikasi Pengetahuan}

Identifikasi adalah kegiatan yang mencari, menemukan, mengumpulkan, mene-liti, mendaftarkan, mencatat data dan informasi dari kebutuhan lapangan.Sedangkan pengetahuan adalah informasi yang telah dikombinasikan dengan pemahaman dan potensi yang melekat dibenak seseorang. Jadi identifikasi pengetahuan adalah suatu kegiatan mengumpulkan serta mencatat informasi yang telah dikombinasikan dengan potensi yang melekat dibenak seseorang. Hal ini dapat dilaksanakan dengan berbagai kegiatan yaitu : 


\section{a. Bercocok Tanam}

Bercocok tanam merupakan kegiatan dalam sektor pertanian.Pengetahuan tentang bercocok tanama kelompok tani karya bersama dapat dilihat pada Tabel 3, di mana identifikasi sumber-sumber pengetahuan bercocok tanam dalam penelitan ini berasal/bersumber dari Dinas Pertanian Kecamatan, Dinas Pertanian Kabupaten,Media masa, dan Pengalaman. Sumber pengetahuan tentang bercocok tanam terjadi ketika pihak atau instansi Dinas Pertanian Kecamatan dan Dinas Pertanian Kabupaten berkunjung ke kelompok tani untuk memberikan penjelasan tentang program agar bersinergi dengan program kelompok tani karya bersama dan memantau kegiatan yang sementara dilaksanakan sekaligus kegiatan monitoring evaluasi (Monev) terhadap capaian kerja. Sumber pengetahuan selanjutnya adalah melalui media masa dan pengalaman. Melalui media, para petani banyak memperoleh informasi mengenai pertanian yang dikembangkan disuatu tempat yang memiliki kesamaan antara lain iklim, cuaca dan tanah, sedangkan melalui pengalaman terjadi dengan mencontoh pada keberhasilan orang lain yang pada akhirnya mengawinkan antara teori dengan pengalaman. Tabel 3 menggambarkan tentang proses identifikasi sumber pengetahuan tentang bercocok tanam pada kelompok tani karya bersama.

Tabel 3. Mengidentifikasi Sumber Pengetahuan Cara Bercocok Tanam

\begin{tabular}{llccc}
\hline \multicolumn{4}{c}{ Cara Bercocok Tanam } \\
No & $\begin{array}{c}\text { Sumber } \\
\text { Pengetahuan }\end{array}$ & $\mathbf{N}$ & $\begin{array}{c}\text { Jumlah } \\
\text { Responden } \\
\text { (orang) }\end{array}$ & $\begin{array}{c}\text { Persentase } \\
(\%)\end{array}$ \\
\hline 1. & $\begin{array}{l}\text { Dinas pertanian } \\
\text { kecamatan }\end{array}$ & 20 & 14 & 70 \\
2. & $\begin{array}{l}\text { Dinas pertanian } \\
\text { kabupaten }\end{array}$ & 20 & 8 & 40 \\
3. & Media masa & 20 & 12 & 60 \\
4. & Pengalaman & 20 & 17 & 85 \\
\hline \multicolumn{5}{l}{ Sumber: Diolah data primer, 2016. }
\end{tabular}

Tabel 3 menunjukkan bahwa 17 responden $(85 \%)$ mengetahui cara bercocok tanam dari pengalaman para petani yang sukses atau orang yang lebih mengerti, 14 responden $(70 \%)$ didapat dari penyuluh dinas pertanian kecamatan, 12 responden $(60 \%)$ dari media masa, dan 8 responden $(40 \%)$ dari penyuluh dinas pertanian kabupaten. Sumber pengetahuan petani didapat dari petani yang sukses, yang dimaksud dengan petani sukses ialah orang tua atau petani yang sudah berpengalaman banyak dalam hal bertani. Selain itu sumber pengetahuan diperoleh dari penyuluh dinas pertanian kecamatan dikarenakan sebagian anggota merupakan anggota pemula yang belum berpengalaman banyak dalam bercocok tanam. Selanjutnya sumber pengetahuan didapat dari media masa melalui buku, televisi, radio, koran, karena sebagian anggota gemar membaca sehingga menjadikan buku sebagai sumber informasi dan buku diperoleh dari kegiatan pameran, serta kegiatan penyuluhan pertanian. Sebagian anggota memperoleh pengetahuan lewat siaran televisi mengenai keberhasilan petani disuatu tempat.Juga siaran radio menjadi sumber pengetahuan, karena sebagian anggota memiliki radio dan gemar mendengarkan siaran khusus pertanian.

\section{b. Kehadiran Penyuluh}

Kelompok tani karya bersama mendapat kunjungan dari penyuluh kurun waktu setahun apabilah ada bantuan pemerintah untuk dikelolah oleh kelompok tani, juga disaat mereka memantau perkembangan usaha yang dilakuakan oleh kelomopok tani ataukah diundang oleh kelompok ketika mendapat permasalahan dalam usaha kelompok untuk mendapatkan solusi. Selain itu juga ketika panen hasil kelompok tani juga mengundang penyuluh untuk mengetahui sejauh mana keberhasilan kelompok tani, tapi ada juga kehadiran penyuluh sudah merupakan program kerja dari Dinas Pertanian. Tabel 4 menunjukan bahwa terdapat sebanyak 17 responden (85\%), dalam setahun menghadiri pertemuan sebanyak 3-4 kali, sedangkan hanya terdapat 3 responden (15\%) mengikuti pertemuan sebanyak lebih 4 kali. Ini dikarenakan anggota kelompok diluar pengurus berjumlah 17 responden sehingga seluruh anggota mengikuti pertemuan, sedangkan $15 \%$ atau 3 responden adalah pengurus yang mengikuti 
lebih dari 4 kali karena ada program pertemuan penyuluh dengan GAPOKTAN yang hanya diwakili pengurus kelompok tani.

Tabel 4. Mengidentifikasi Sumber Pengetahuan Dilihat dari Kehadiran Penyuluh

\begin{tabular}{cccc}
\hline No & Kehadiran & $\begin{array}{c}\text { Jumlah } \\
\text { Responden } \\
\text { (orang) }\end{array}$ & $\begin{array}{c}\text { Persentase } \\
(\boldsymbol{\%})\end{array}$ \\
\hline 1. & $1-2 \mathrm{kali}$ & - & - \\
2. & $3-4 \mathrm{kali}$ & 17 & 85 \\
3. & $>4 \mathrm{kali}$ & 3 & 15 \\
\hline Jumlah & $\mathbf{2 0}$ & $\mathbf{1 0 0}$ \\
\hline
\end{tabular}

\section{c. Program-Program dan Materi Penyuluh}

Keberhasilan suatu kelompok tani akan tergantung pada kemampuan anggota untuk memahami program program yang diberikan oleh penyuluh pertanian. Beberapa program yang ditawarkan penyuluh diantaranya penyiapan lahan, pemilihan bibit unggul, cara menanam, pemanenan.Lahan mutlak harus ada oleh sebab itu pimpinan kelompok tani terlebih dahulu mendata anggota yang memiliki lahan yang cukup luas untuk dijadikan tempat kegiatan agar supaya mengetahui kecocokan lahan yang digunakan maka terlebih dahulu disurvey oleh pengurus dan anggota. Pada saat tim penyuluh turun ke kelompok tani, mereka menjelaskan pada kelompok tentang cara memilih bibit unggul yang sesuai dengan lingkungan alam sekitar. Karena bibit yang unggul bagi daerah tertentu belum tentu unggul di daerah lain.Sekalipun bibit itu unggul namun cara menanam tidak sesuai ketentuan maka akan mempengaruhi hasil panen nanti. Pada saat panen harus sesuai dengan waktu/usia panen sebab jika belum waktunya panen mempengaruhi mutu hasil panen tersebut, demikian juga apabilah waktu panenennya melebihi dari umur panen dapat dilihat pada Tabel 5.

Tabel 5. Mengidentifikasi Sumber Pengetahuan dari

\begin{tabular}{|c|c|c|c|c|}
\hline \multicolumn{5}{|c|}{ Program-Program Penyuluh } \\
\hline No & Program & $\mathbf{N}$ & $\begin{array}{c}\text { Jumlah } \\
\text { Responden } \\
\text { (orang) }\end{array}$ & $\begin{array}{c}\text { Persentase } \\
(\%)\end{array}$ \\
\hline 1. & Penyiapan lahan & 20 & 17 & 85 \\
\hline 2. & $\begin{array}{l}\text { Pemilihan bibit } \\
\text { unggul }\end{array}$ & 20 & 15 & 75 \\
\hline 3. & Cara menanam & 20 & 18 & 90 \\
\hline 4. & Pemanenan & 20 & 16 & 80 \\
\hline
\end{tabular}

Tabel 5 menunjukkan bahwa materi penyuluhan tentang cara menanam yang diketahui oleh kelompok tani adalah sebanyak 18 responden $(90 \%)$ tentang cara menanam, sebanyak 17 responden (85\%) cara penyiapan lahan sebanyak 16 responden (80\%) pemanenan, dan pemilihan bibit unggul sebanyak 15 responden (75\%). Dalam tabel ini menunjukan sebanyak 18 responden (90\%) mengetahui cara menanam yang baik lewat pengalaman mereka karena itu merupakan pekerjaan yang sudah biasa mereka lakukan.Penyiapan lahan sebanyak 17 responden (85\%) yang mengetahui cara penyiapan lahan, karena tidak semua anggota kelompok mengetahui dan mengerti cara untuk penyiapan lahan karena lahan yang mereka miliki masing-masing berbeda letaknya. sebanyak 16 responden (80\%) yang mengetahui pemanenan yang baik dan sebanyak 15 responden $(75 \%)$ yang mengerti bagaimana cara pemilihan bibit unggul untuk di tanam.

d. Identifikasi Pengetahuan Berdasarkan Anggota Setiap anggota memiliki kemampuan yang berbeda dalam hal mendapatkan pengetahuan tentang pertanian, diantaranya membaca buku,menonton televisi, mendengarkan radio, membaca koran,mengikuti pelatihan, mengikuti penyuluhan. Tabel 6 menjelaskan tentang kemampuan mengidentifikasi pengetahuan koresponden berdasarkan membaca buku, menonton televisi, mendengar radio, membaca koran, mengikuti pelatihan dan mengikuti penyuluhan dapat dilihat pada Tabel 6 .

Tabel 6. Mengidentifikasi Pengetahuan

\begin{tabular}{clccc}
\hline No & $\begin{array}{c}\text { Identifikasi } \\
\text { Pengetahuan }\end{array}$ & N & $\begin{array}{c}\text { Jumlah } \\
\text { Responden } \\
\text { (orang) }\end{array}$ & $\begin{array}{c}\text { Persentase } \\
(\%)\end{array}$ \\
\hline 1. & $\begin{array}{l}\text { Membaca Buku } \\
\text { 2. }\end{array}$ & 20 & 13 & 65 \\
Menonton & 20 & 19 & 95 \\
3. & Melevisi & 16 & 80 \\
4. & Mendengar Radio & 20 & 12 & 60 \\
5. & $\begin{array}{l}\text { Mengikuti } \\
\text { Pelatihan }\end{array}$ & 20 & 16 & 80 \\
6. & $\begin{array}{l}\text { Mengikuti } \\
\text { Penyuluhan }\end{array}$ & 20 & 15 & 75 \\
\hline
\end{tabular}

Tabel 6 menunjukkan bahwa 19 responden $(95 \%)$ mendapat pengetahuan dari menonton televisi karena banyak anggota kelompok yang mengisi waktu luang ketika kembali dari kebun dengan menonton televisi. Sebanyak 17 responden (85\%) mengetahui ketika mereka mengikuti seminar yang dilaksanakan oleh Dinas Pertanian. Sebanyak 16 responden (80\%) mendapat pengetahuan dengan mendengarkan radio di rumah. 16 responden 
(80\%) mengetahui dengan mengikuti pelatihan. $75 \%$ atau sebanyak 15 responden mendapat pengetahuan dengan mengikuti penyuluhan yang juga dilakukan oleh dinas pertanian. 13 responden (65\%) sebanyak mendapat pengetahuan dan memiliki hobi untuk membaca buku. Dan sebanyak 13 responden $(65 \%)$ mendapat pengetahuan dengan membaca buku. Tabel 6 dapat dilihat paling banyak responden mendapatkan pengetahuan lewat menonton televisi dikarenakan semua anggota memiliki televisi di rumah masing-masing sehingga memudahkan anggota untuk melihat menyaksikan dan mendengarkan siaran televisi berkaitan dengan informasi pertanian. Dan paling sedikit responden mendapatkan informasi/ pengetahuan dari membaca koran, ini dikarenakan tidak adanya koran yang dibaca,tidak mau membaca dan tidak bisa membaca dapat dilihat pada Tabel 7.

\section{e. Frekuesi Aktivitas Membaca Buku}

Tabel 7 menunjukkan bahwa 5 responden (25\%) membaca buku dalam seminggu sebanyak 2 kali, juga 5 responden (25\%) membaca buku 1 kali dalam seminggu, sedangkan 3 responden (15\%) membaca buku lebih dari 3 kali dalam seminggu. Sehingga jumlah keseluruhan anggota yang membaca buku 13 responden dari 20 responden, ini dikarenakan ada anggota yang tidak tahu membaca juga kurangnya kemauan untuk membaca buku.Lewat membaca anggota mengetahuai tentang cara menyiapkan lahan, cara memilih bibit yang unggul,cara menanam, cara merawat tanaman, cara memupuk, cara membasmi hama, cara memanen dan pengelolahan hasil pertanian. Menonton televisi juga menjadi salah satu bagian dari media petani untuk mendapatkan informasi, dengan menyaksikan acara televisi mengenai pertanian anggota lebih jelas melihat karena ada gambar, video, suara yang memudakan anggota menyerap informasi yang diterimah tentang cara bercocok tanam atau kegiatan berkaitan dengan pertanian.Petani memanfaatkan waktu lowong ketika pulang dari bertani untuk menyaksikan siaran televise dapat dilihat pada Tabel 8.

Tabel 7. Frekuensi Aktivitas Membaca Buku

\begin{tabular}{ccccc}
\hline No & $\begin{array}{c}\text { Frekuensi / } \\
\text { minggu }\end{array}$ & $\mathbf{N}$ & $\begin{array}{c}\text { Responden } \\
\text { (orang) }\end{array}$ & $\begin{array}{c}\text { Persentase } \\
(\%)\end{array}$ \\
\hline 1. & $1 \mathrm{X}$ & 20 & 5 & 25 \\
2. & $2 \mathrm{X}$ & 20 & 5 & 25 \\
3. & $>3 \mathrm{X}$ & 20 & 3 & 15
\end{tabular}

\section{f. Frekuensi Aktivitas Menonton}

Tabel 8 menunjukkan bahwa 8 responden (40\%) menonton televisi sebanyak 2 kali dalam seminggu,juga 7 responden $(35 \%)$ menonton televisi lebih dari 3 kali seminggu, dan 4 responden (20\%) menonton televisi 1 kali dalam seminggu. Dari 20 responden ada 19 responden yang menjadikan televisi sebagai sarana informasi, sehingga bisa kita lihat bahwa hampir semua anggota menonton televisi, ini dikarenakan semua anggota memiliki televisi di rumah masing-masing sehingga tidak sulit dan memakan waktu.

Tabel 8. Mengidentifikasi Pengetahuan Berdasarkan Anggota

\begin{tabular}{ccccc}
\multicolumn{5}{c}{ Menonton Televisi } \\
No & $\begin{array}{c}\text { Frekuensi / } \\
\text { minggu }\end{array}$ & N & $\begin{array}{c}\text { Responden } \\
\text { (orang) }\end{array}$ & $\begin{array}{c}\text { Persentase } \\
(\%)\end{array}$ \\
\hline 1. & $1 \mathrm{X}$ & 20 & 4 & 20 \\
2. & $2 \mathrm{X}$ & 20 & 8 & 40 \\
3. & $>3 \mathrm{X}$ & 20 & 7 & 35 \\
\hline
\end{tabular}

g. Frekuensi Aktivitas Mendengar Radio

Mendengarkan radio menjadi salah satu sumber pengetahuan, karena sebagian anggota memiliki radio dan gemar mendengarkan siaran khusus pertanian.Lewat perkembangan modern hampir semua anggota memiliki hp yang dalamnya memiliki aplikasi radio sehingga memudakan anggota mendengarkan radio walau berada di perkebunan dapat dilihat pada Tabel 9. Tabel 9 menunjukkan bahwa 7 responden (35\%) yang mendengarkan siaran radio khusus pertanian 1 kali dalam seminggu, 5 responden (25\%) yang mendengarkan siaran radio mengenai pertanian lebih dari 3 kali seminggu, dan 4 responden (20\%) yang mendengarkan siaran radio mengenai pertanian 2 kali dalam seminggu. Informasi yang didengar ialah kesuksesan petani dalam suatu kegiatan bertani, juga lewat radio mereka mengetahui apabila akan diadakan penyuluhan atau seminar mengenai pertanian di wilayah anggota tinggal, juga sarana informasi mengenai bantuan pemerintah.

Tabel 9. Mengidentifikasi Pengetahuan Berdasarkan

\begin{tabular}{ccccc}
\multicolumn{5}{c}{ Anggota Mendengar Radio } \\
\hline No & $\begin{array}{c}\text { Frekuensi / } \\
\text { minggu }\end{array}$ & N & $\begin{array}{c}\text { Responden } \\
\text { (orang) }\end{array}$ & $\begin{array}{c}\text { Persentase } \\
(\%)\end{array}$ \\
\hline 1. & $1 \mathrm{X}$ & 20 & 7 & 35 \\
2. & $2 \mathrm{X}$ & 20 & 4 & 20 \\
3. & $>3 \mathrm{X}$ & 20 & 5 & 25 \\
\hline
\end{tabular}

h. Frekuensi Aktivitas Membaca Koran

Salah satu informasi yang didapat petani lewat membaca koran, dimana lewat 
berita koram menjelaskan keadaan petani di daerah kita saat ini tentang kondisi pertanian diantaranya gagal panen dikarenakan cuaca buruk juga hama penyakit. Lewat berita koran juga petani menjumpai iklan-iklan mengenai produk bibit tanaman atau pembasmi hama pada tanaman. Pada Tabel 10 akan dilihat jumlah responden yang membaca koran dalam seminggu dapat dilihat pada Tabel 10. Tabel 10 menunjukkan bahwa 7 responden (35\%) yang membaca koran hanya sekali dalam seminggu, 3 responden (15\%) yang membaca koran dua kali dalam seminggu, dan 2 responden (10\%) membaca koran lebih dari tiga kali dalam seminggu. Faktor yang mempengaruhi jumlah responden menjadikan koran sebagai media adalah ada anggota yang tidak bisa membaca,tidak gemar membaca juga dikarenakan fasilitas tidak ada.

Tabel 10. Mengidentifikasi Pengetahuan Berdasarkan

\begin{tabular}{ccccc}
\multicolumn{5}{c}{ Anggota Membaca Koran } \\
\hline No & $\begin{array}{c}\text { Frekuensi / } \\
\text { minggu }\end{array}$ & $\mathbf{N}$ & $\begin{array}{c}\text { Responden } \\
\text { (orang) }\end{array}$ & $\begin{array}{c}\text { Persentase } \\
(\%)\end{array}$ \\
\hline 1. & $1 \mathrm{X}$ & 20 & 7 & 35 \\
2. & $2 \mathrm{X}$ & 20 & 3 & 15 \\
3. & $>3 \mathrm{X}$ & 20 & 2 & 10 \\
\hline
\end{tabular}

i. Frekuensi Aktivitas Mengikuti Pelatihan

Salah satu sumber informasi atau pengetahuan yang didapat petani ialah mengikuti Salah satu sumber informasi atau pengetahuan yang didapat petani ialah mengikuti pelatihan. Dalam kegiatan ini anggota kelompok secara langsung mendengar juga melihat cara menanam, jarak tanam, penyiapan beni unggul, pengelolaan tanaman, hama penyakit tanaman, pengelolahan hasil pertanian juga pengunaan alat pertanian. Tabel 11 menunjukkan bahwa 8 responden (40\%) mengikuti pelatihan 2 kali dalam setahun, 6 responden (30\%) mengikuti lebih dari 3 kali dalam setahun sedangkan 2 responden (10\%) mengikuti 1 kali dalam setahun.

Tabel 11. Mengidentifikasi Pengetahuan Berdasarkan Anggota Mengikuti Pelatihan

\begin{tabular}{ccccc}
\hline No & $\begin{array}{c}\text { Frekuensi / } \\
\text { Tahun }\end{array}$ & N & $\begin{array}{c}\text { Responden } \\
\text { (Orang) }\end{array}$ & $\begin{array}{c}\text { Persentase } \\
(\%)\end{array}$ \\
\hline 1. & $1 \mathrm{X}$ & 20 & 2 & 10 \\
2. & $2 \mathrm{X}$ & 20 & 8 & 40 \\
3. & $>3 \mathrm{X}$ & 20 & 6 & 30 \\
\hline
\end{tabular}

j. Frekuesi Aktivitas Mengikuti Penyuluhan

Mengikuti penyuluhan juga jadi salah satu sumber informasi pengetahuan petani, karena lewat mengikuti penyuluhan anggota akan mendapatkan pengetahuan tentang cara menanam, jarak tanam, penyiapan beni unggul, pengelolaan tanaman, hama penyakit tanaman, pengelolahan hasil pertanian. Dan yang memberikan penyuluhan dari dinas pertanian kecamatan dan dinas pertanian kabupaten yang diprogramkan oleh dinas pertanian untuk kegiatan penyuluhan juga ada waktu di mana kelompok tani yang mengundang utuk diadakan kegiatan penyuluhan.

Tabel 12. Mengidentifikasi Pengetahuan Berdasarkan Anggota Mengikuti Penyuluhan

\begin{tabular}{ccccc}
\hline No & $\begin{array}{c}\text { Frekuensi/ } \\
\text { Tahun }\end{array}$ & $\mathbf{N}$ & $\begin{array}{c}\text { Responden } \\
\text { (orang) }\end{array}$ & $\begin{array}{c}\text { Persentase } \\
(\%)\end{array}$ \\
\hline 1. & $2 \mathrm{X}$ & 20 & 2 & 10 \\
2. & $3 \mathrm{X}$ & 20 & 6 & 30 \\
3. & $>3 \mathrm{X}$ & 20 & 7 & 35 \\
\hline & Tabel & 12 & menunjukkan & bahwa
\end{tabular}
responden $(35 \%)$ yang mengikuti kegiatan penyuluhan lebih dari 3 kali dalam setahun, 6 responden (30\%) yang mengikuti 3 kali penyuluhan dalam setahun dan 2 responden (10\%) yang mengikuti penyuluhan 2 kali dalam setahun.

\section{Penciptaan Pengetahuan}

Pertemuan antar kelompok tani rutin diadakan dan manfaat dari pertemuan ini untuk menjalin hubungan antar sesama anggota juga saling berbagi pengalaman dalam kegiatan pertanian yang sudah berjalan, juga kegiatan ini menjadikan wadah anggota untuk saling tukar pikiran dalam perencanaan suatu usaha pertanian yang dijelaskan pada Tabel 13.

Tabel 13. Penciptaan Pengetahuan Berdasarkan Pertemuan antar Anggota Kelompok Tani

\begin{tabular}{ccccc}
\hline No & $\begin{array}{c}\text { Frekuensi / } \\
\text { Bulan }\end{array}$ & N & $\begin{array}{c}\text { Responden } \\
\text { (orang) }\end{array}$ & $\begin{array}{c}\text { Persentase } \\
(\boldsymbol{\%})\end{array}$ \\
\hline 1. & $1 \mathrm{X}$ & 20 & 4 & 20 \\
2. & $2 \mathrm{X}$ & 20 & 16 & 80 \\
3. & $>3 \mathrm{X}$ & 20 & - & - \\
\hline
\end{tabular}

Tabel 13 menunjukkan bahwa sebanyak 16 responden $(80 \%)$ mengikuti pertemuan 2 kali dalam sebulan, dan 4 responden $(20 \%)$ mengikuti pertemuan 1 kali 
dalam sebulan. Peran dari Gapoktan. Gapoktan adalah gabungan kelompok tani yang bertujuan untuk menghimpun semua kelompok dalam satu wadah untuk mengkomunikasikan program kerja terkait dengan dinas pertanian kecamatan dan dinas pertanian kabupaten. Selanjutnya dalam gapoktan terdapat kegiatan untuk menampilkan keunggulan dari setiap kelompok tani, sehingga lewat kegiatan tersebut dapat menjadi pembelajaran bagi kelompok lainnya. Dan pengurus gapoktan diambil dari perwakilan kelompok-kelompok tani melalui pemilihan pengurus, ketika ada bantuan diolah secara bersama dan didistribusikan secara proporsional ke kelompok-kelompok tani yang tergabung dalam gapoktan. Gapoktan diharapkan dapat menjalankan fungsi kemitraan dengan adil dan saling menguntungkan dengan pedagang saprotan maupun pedagang hasil-hasil pertanian (Syahyuti, 2007).

Tabel 14. Penciptaan Pengetahuan Berdasarkan Peran dari Gapoktan

\begin{tabular}{llccc}
\hline No & $\begin{array}{l}\text { Peran } \\
\text { Gapoktan }\end{array}$ & N & $\begin{array}{c}\text { Responden } \\
\text { (orang) }\end{array}$ & $\begin{array}{c}\text { Persentase } \\
(\%)\end{array}$ \\
\hline 1. & Memecakan & 20 & 20 & 100 \\
permasalahan & 20 & 20 & 100 \\
2. & Berbagi ilmu & 20 & 20 & 100 \\
3. & Sarana bantuan & 20 & 20 \\
\hline
\end{tabular}

Tabel 14 menunjukkan bahwa seluruh anggota menyerap ilmu yang dibagikan untuk kemudian diperaktekan dalam lapangan, dan ketika mendapatkan permasalahan akan dibahas bersama untuk mencari solusi/ jalan keluar. Lewat GAPOKTAN juga menjadikan sarana bantuan pemerintah untuk kemudian disalurkan kepada kelompok - kelompok tani yang termasuk dalam GAPOKTAN.

\section{Presentase Pengetahuan}

a. Mempresentasikan Pengetahuan Kepada Kelompok Tani

Dalam kelompok tani pengetahuan terhadap cara bercocok tanam dapat diketahui dengan beberapa cara yaitu, menyaksikan presentasi tentang pemanfaatan teknologi, mendemontrasikan alat alat pertanian, mempresentasikan keberhasilan usaha pertanian.
Tabel 15. Pengeloaan Pengetahuan dengan Cara Mempresentasikan Pengetahuan Kepada Kelompok Tani

\begin{tabular}{ccccc}
\hline No & $\begin{array}{c}\text { Menyaksikan } \\
\text { Peresentasi/ } \\
\text { demonstrasi } \\
\text { tentang } \\
\text { pemanfaatan } \\
\text { teknologi }\end{array}$ & N & $\begin{array}{c}\text { Responden } \\
\text { (orang) }\end{array}$ & $\begin{array}{c}\text { Persentase } \\
(\%)\end{array}$ \\
\hline 1. & Menyaksikan & 20 & 20 & 100 \\
2. & Tidak & & \\
& menyaksikan & 20 & - & - \\
\hline
\end{tabular}

Tabel 15 menunjukkan bahwa seluruh anggota kelompok meyaksikan persentasi/ demonstrasi tentang pemanfaatan teknologi karena pentingnya kegiatan ini sehubungan dengan pengetahuan yang akan didapat dari pertemuan tersebut.

b. Mendemonstrasikan alat-alat pertanian.

Kelompok tani mendapat bantuan langsung dari Dinas Pertanian Kabupaten berupa alat pemupil jagung dan spreyer. Sebelum digunakan didemonstrasikan terlebi dahulu oleh petugas cara menggunakannnya.

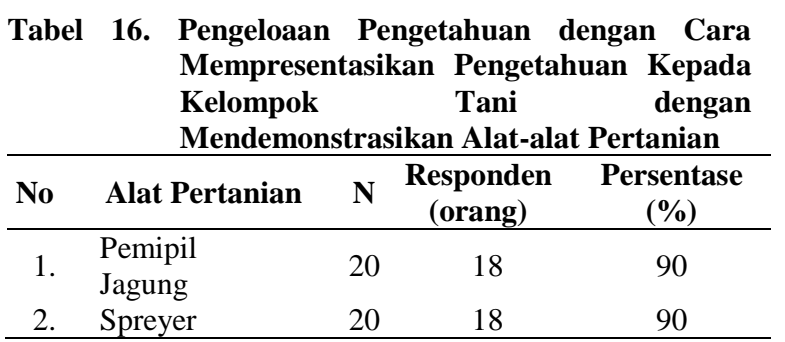

Tabel 16 menunjukkan anggota yang mengikuti demonstrasi alat-alat pertanian.Pemipil jagung dihadiri 18 responden (90\%) dan 18 responden $(90 \%)$ mengikuti demonstrasi alat-alat pertanian. Kegiatan tersebut diadakan satu hari sehingga jumlah anggota yang hadir sama banyak.Dari keseluruhan peserta yang hadir dalam kegiatan demonstrasi tidak semua dapat mengoprasikan alat pemipil jagung karena sebagian anggota adalah wanita.

Tabel 17. Demonstrasi pengoprasian alat pemipil jagung

\begin{tabular}{llccc}
\hline No & $\begin{array}{l}\text { Mengetahui } \\
\text { pengunaan alat } \\
\text { pemipil jagung }\end{array}$ & N & $\begin{array}{c}\text { Responden } \\
\text { (orang) }\end{array}$ & $\begin{array}{c}\text { Persentase } \\
(\%)\end{array}$ \\
\hline 1. & $\begin{array}{l}\text { Sangat } \\
\text { memahami }\end{array}$ & 20 & 11 & 55 \\
2. & Memahami & 20 & 2 & 10 \\
3. & Tidak memahami & 20 & 7 & 35 \\
\hline
\end{tabular}


Tabel 17 menunjukkan bahwa 11 responden $(55 \%)$ sangat memahami pengunaan pemipil jagung, 7 responden (35\%) tidak memahami pengunaan pemipil jagung dan 2 responden $(10 \%)$ memahami pengunaan pemipil jagung. Dari keseluruhan peserta yang hadir dalam kegiatan demonstrasi hampir semua dapat mengoprasikan alat spreyer karena wanita juga ada yang tau mengunakannya

Tabel 18. Demonstrasi pengoprasian alat spreyer

\begin{tabular}{lllcc}
\hline No & $\begin{array}{c}\text { Mengetahui } \\
\text { pengunaan } \\
\text { spreyer }\end{array}$ & $\mathbf{N}$ & $\begin{array}{c}\text { Responden } \\
\text { (orang) }\end{array}$ & $\begin{array}{c}\text { Persentase } \\
\mathbf{( \% )}\end{array}$ \\
\hline 1. & $\begin{array}{l}\text { Sangat } \\
\text { memahami }\end{array}$ & 20 & 14 & 70 \\
2. & Memahami & 20 & 4 & 20 \\
3. & Tidak memahami & 20 & 2 & 10 \\
\hline
\end{tabular}

Tabel 18 menunjukkan bahwa 14 responden (70\%) sangat memahami pengunaan spreyer, 4 responden $(20 \%)$ memahami pengunaan spreyer, dan 2 responden $(10 \%)$ tidak memahami cara pengunaan spreyer.

\section{Distribusi Pengetahuan}

Mendistribusikan pengetahuan dilakukan oleh pengurus kepada anggota dengan cara memperbanyak bahan bacaan didapat dari pelatihan yang hanya diikuti oleh pengurus dengan cara mengcopy materi untuk dibagikan kepada semua anggota. Selanjutnya pada saat ada pertemuan rutin pimpinan mempertanyakan kalau ada yang belum dimengerti kemudian dibahas bersama. Dengan demikian secara utuh pengetahuan yang diperoleh pimpinan lewat pelatihan dapat dimengerti oleh semua anggota sehingga dalam satu pertemuan bisa saja berkembang metode diskusi, tanya jawab, interaktif antara pimpinan pengurus dan anggota.

Tabel 19. Frekuesni penyebaran pengetahuan pengurus kepada anggota kelompok.

\begin{tabular}{cllcc}
\hline \multirow{2}{*}{ No } & \multirow{2}{*}{ Pengurus } & \multicolumn{3}{c}{ Frekuensi / 3 bulan } \\
\cline { 3 - 5 } & & $\mathbf{1} \mathbf{x}$ & $\mathbf{2 x}$ & $\mathbf{3 x}$ \\
\hline 1 & Ketua & & $\sqrt{ }$ & $\sqrt{ }$ \\
2 & Sekretaris & & $\sqrt{ }$ & $\sqrt{ }$ \\
3 & Bendahara & & & $\sqrt{ }$ \\
\hline
\end{tabular}

Tabel 19 menunjukkan bahwa ketua kelompok tani dalam tiga bulan mendistribusikan pengetahuan kepada anggota sebanyak tiga kali, selanjutnya sekretaris mendistribusikan pengetahuan dalam tiga bulan sebanyak dua kali, dan bendahara kelompok tani mendistribusikan bantuan sebayak tiga kali dalam tiga bulan. Proses penyebaran pengetahuan oleh pengurus tersebut diharapkan akan mampu memberikan pemahaman bagi anggota terhadap pengetahuan-pengetahuan yang diberikan. Tabel berikut hasil penelitian tentang pemahaman pengetahuan yang disalurkan / disebarkan oleh pengetahuan cukup paham dan dapat dilihat pada Tabel 20.

Tabel 20. Tingkat Pemahaman Anggota

\begin{tabular}{clccc}
\hline No & $\begin{array}{c}\text { Tingkat } \\
\text { Pemahaman }\end{array}$ & N & Responden & \% \\
\hline 1 & Paham & 17 & 15 & 90 \\
2 & Cukup pahaman & 17 & 2 & 10 \\
3 & Tidak paham & 17 & - & - \\
\hline
\end{tabular}

Tabel 20 menunjukkan bahwa tingkat pemahaman anggota yang menerima pengetahuan dari pimpinan sebayak 15 responden $(90 \%)$, anggota yang cukup paham 2 responden $(10 \%)$ dan tidak didapati responden yang tidak paham.

\section{KESIMPULAN DAN SARAN}

\section{Kesimpulan}

Berdasarkan uraian hasil dan pembahasan, maka dapat disimpulkan bahwa sumber pengetahuan bercocok tanam bersumber dari dinas pertanian Kecamatan, Kabupaten, media masa dan pengalaman. Selain itu anggota kelompok tani memperoleh pengetahuan lewat menonton TV, membaca koran dan buku. Dari hasil penelitian ini terlihat bahwa penciptaan pengetahuan melalui pertemuan antar kelompok tani secara rutin sehingga terjadi komunikasi sesama anggota, saling membagi pengetahuan sehingga menambah wawasan dari anggota lain, selain itu di desa dibentuk gapoktan sebagai wadah menghimpun semua kelompok tani yang ada di desa yang pengurusnya diambil dari perwakilan semua kelompok tani. Melalui gapoktan juga menjadikan sarana bantuan pemerintah kemudian disalurkan kepada kelompok tani yang termasuk dalam gapoktan. Dan dalam kelompok tani pengetahuan tentang cara bercocok tanam dapat diketahuai dengan beberapa cara yakni : a) menyaksikan presentasi tentang pemanfaatan teknologi dan hasil penelitian membuktikan bahwa semua anggota kelompok menyaksikan presentasi tentang pemanfaatan teknologi. b) mendemonstrasikan alat-alat yang merupakan bantuan dari pemerintah berupa alat pemipil jagung dan spreyer. Serta 
dalam mendistribusikan pengetahuan kepada anggota dilakuakan pengetahuan dengan cara memperbanyak buku bacaan diperoleh pengurus dalam penelitian selanjutnya untuk memanfaatkan pengetahuan anggota maka pengurus membentuk pertemuan dengan anggota untuk mendistribusikan hal-hal yang belum dipahami oleh anggota.

\section{Saran}

Perlu adanya program perencanaan dari kelompok tani untuk mengundang penyuluh pertanian baik ditingkat Kecamatan maupun Kabupaten untuk memberikan pengetahuan sekalipun tidak bertepatan dengan adanya bantuan pemerintah, mengingat berbagai permasalahan dalam usaha pertanian terkadang tidak atau sulit mendapat solusinya. Pertemuan antar anggota kelompok tani secara rutin harus tetap dipertahankan karena sangat bermanfaat bagi anggota untuk saling tukar pikiran dalam suatu usaha pertanian. Demikian juga dengan pertemuan yang dilakukan melalui gapoktan agar tidak terbatas pengurusnya saja tapi langsung melibatkan semua anggota. Dan Setiap anggota kelompok tani hedaknya mengetahui cara pengunaan alat-alat pertanian dan apabila masih ada anggota yang belum paham maka oleh pimpinan kelompok dapat melatih berulang-ulang sampai mereka mengetahui cara pengunaan alat-alat tersebut. Pengurus kelompok tani lebih proaktif untuk mendapatkan informasi pengetahuan tentang pertanian melalui dinas pertanian dan dinas terkait lainnya serta memanfaatkan teknologi informasi melalui internet yang kemudian dibahas bersama dalam kelompok

\section{DAFTAR PUSTAKA}

Budihardjo Andreas. 2016. Knowledge Management - Efektif Berinovasi Meraih Sukses (Cetakan 1). Jakarta: Prasetiya Mulya Publishing.

Bungin, Burhan. 2003. Metodologi Penelitian Kualitatif. Cet. 2. Jakarta: PT Raja Grafindo Persada.

Choo Chun Wei, The Knowing Organization: How Organizations Use Information To Construct Meaning, Create Knowledge, And Make Decisions. NewYork: Oxford University Press, 2006.
Deveau. D. Knowledge is Business power in computing Canada, no. 26/8, April, p. 14.

Loermans, J. 2002. Synergizing the Larning Organization. Jurnal of Knowledge Management. Vol. 6, No. 3, pp. 285-294.

Mardikanto, T. 1996. Penyuluhan Pembangunan Kehutanan. Departemen Kehutanan. Jakarta.http://turindraatp.Blogspot.co .id /2009/12/pengertian-kelompok-tani.html. Diakses tanggal 16 Mei 2016.

Mathew, Mercy (ed.) (2009), Case Studies on Business Environment - Vol. 1, IBS Case Development Center, Andhra Pradesh, India.http://image.kadin-indonesia.Or.id /images/file/kadinindonesia20120607133 150.pdf. Diakses tanggal 16 Mei 2016.

Putra Valiano Dwi Nugroho, Pengantar Bisnis Manajemen dan Organiasasi. Universitas Gunadarma. https://valvaliano. wordpress. com/2013/11/15/manajemendan organisasi/. Diakses tanggal 16 Mei 2016.

Richard Arthur Tutu, Tugas Pengantar Manajemen - Pengertian dan FungsiFungsi Manajemen Menurut Para Ahli, 2013. http://blogku10061987.blogspot. co.id/2014/10/pengertian-dan-fungsi-

fungsi-manajemen.html. Diakses tanggal 16 Mei 2016.

Rahma Septiana, Manajemen Menurut Pendapat Profesor OEI LIANG LEE Dan Implementasinya Dalam Pendidikan. 2015.http://dinirahmasep tiana.blogspot. co.id/2015/05/manajemen-menurut-penda pat-profesor-oei.html. Diakses tanggal 16 Mei 2016.

Sri Nuryanti dan Dewa K. S. Swastika, Peran Kelompok Tani Dalam Penerapan Teknologi Pertanian.Pusat Sosial Ekonomi dan Kebijakan Pertanian (2011). http://pse.litbang.pertanian.go. id/ind/pdff iles/FAE29-2d.pdf. Diakses tanggal 16 Mei 2016.

Syahyuti. 2007. Kebijakan Pengembangan Gabungan Kelompok Tani (Gapoktan) Sebagai Kelembagaan Ekonomi di Pedesaan. Pusat Analisis Sosial Ekonomi dan Kebijakan Pertanian, Bogor. 